\title{
A Revelação de Jesus Cristo como sentido e plenitude do mistério do ser humano
}

\author{
Orientador: Paulo Cezar Costa \\ Mestrando: Angela Cristina Germine Pinto Caldeira \\ Área de Concentração: Teologia Sistemático-Pastoral \\ Linha de Pesquisa: Religião e Modernidade
}

O horizonte teológico, assim como a realidade humana, é um desafio a enfrentar na atualidade Para os cristãos, Jesus Cristo, suas palavras e ações se tornam a perspectiva por meio da qual se avalia a realidade. A dissertação tem como objeto o princípio cristológico na relação entre Criação e Salvação. Para tal, primeiramente, foi feita uma revisão dos textos bíblicos e da tradição sobre a criação do homem e sua relação com Deus, para evidenciar o direcionamento da criação para a salvação em Cristo. A Constituição Gaudium et Spes declarou que o fundamento do ser humano e do seu destino último só pode ser compreendido a partir do mistério de Cristo. A partir do princípio cristológico buscou-se apresentar o ministério de Jesus e a importância do tema do seguimento para evidenciar como o ser humano adquire sua identidade em Cristo. Por fim, através da discussão do significado teológico da ressurreição foi possível demonstrar que a esperança permanece radicada na vitória de Cristo, e, portanto, que já pode ser experimentada na perspectiva da produção de sentido para a vida humana, recuperando sua fonte mais genuína em Cristo. Concluiuse que o ser humano é criado em Cristo, e traz em si a imagem de Deus que é Cristo, pois na encarnação o ser humano visualiza Aquele do qual foi criado imagem, Cristo, e o seu caminho no seguimento de Jesus participando do Reino de Deus. Por isso, Cristo é a identidade e a esperança do ser humano.

Palavras-chave: Criação e Salvação; Encarnação; Jesus Cristo. 